\title{
Valores políticos dos agentes pedagógicos dos projetos de educação para a democracia do Congresso Nacional
}

\author{
Antonio Teixeira de Barros \\ Professor doutor do Programa de Pós-graduação do Centro \\ de Formação da Câmara dos Deputados, Brasil \\ antonibarros@gmail.com \\ Rildo Cosson \\ Professor doutor do Programa de Pós-graduação do Centro \\ de Formação da Câmara dos Deputados, Brasil \\ rcosson@gmail.com
}

Resumo $\mathrm{O}$ artigo analisa a percepção e o discurso dos agentes pedagógicos que atuam nos programas de educação para a democracia do Congresso Nacional. O estudo foi realizado por meio de websurvey, com questões abertas e fechadas no mês de maio de 2017. As principais conclusões demonstram que os educadores são críticos em relação ao atual estágio da democracia e ao combate à corrupção. Há elevada adesão a valores políticos como igualdade de direitos, tolerância política, respeito à diferença e à diversidade cultural e sexual, novas configurações familiares, participação política e social, entre outros. O estudo apresenta dados que são relevantes para a compreensão do modo de pensar de um segmento que atua diretamente nos projetos de educação para a democracia nas duas casas legislativas, considerando que os estudos sobre o tema têm privilegiado os efeitos de tais iniciativas, sem levar em conta a perspectiva dos educadores.

Palavras-chave: Educação para a democracia, Valores políticos, Congresso Nacional, Câmara dos Deputados, Senado Federal.

\section{Introdução}

Vários estudos situam as iniciativas de educação das instituições parlamentares como uma tendência mundial de renovação das tradicionais funções atribuídas aos parlamentos, tais como legislação, representação e fiscalização (Leston-Bandeira, 2009; 2012; Braga; Mitozo; 
Tadra, 2016). Ao acolher os pressupostos positivos da educação política, Ribeiro (2010), por exemplo, ressalta que a função educativa é inerente às atividades legislativas e parlamentares, tendo em vista que os atos de legislar, fiscalizar e representar passam pela deliberação pública, em um processo de socialização política, com ganhos cognitivos tanto para os parlamenteares como para os próprios cidadãos.

No Brasil, há estudos sobre programas de educação para a democracia (Gonçalves; Casalecchi, 2013; Fuks; Casalecchi, 2012; Casalecchi, 2011; Fuks, 2014; Henrique, 2013; 2016; Carvalho, 2009; Cosson, 2010; 2011; 2015; Rocha, 2016; Oddone, 2015; Barros; Martins, 2017a; 2017b; 2017c). Porém, ainda não há nenhuma pesquisa sobre os agentes pedagógicos que atuam nesses programas, ou seja, os educadores, atores indispensáveis do processo educativo. Isso justifica o enfoque aqui apresentado, cujo aprofundamento decorre das seguintes questões: (a) Qual o perfil dos educadores que atuam no âmbito do Poder Legislativo? (b) Quais são os seus valores políticos? Como eles encaram a educação para a democracia no seu cotidiano?

Este estudo fundamenta-se na concepção de que os valores servem de base para a educação para a democracia, no seu sentido amplo. Valores aqui são entendidos como princípios morais e ideológicos que influenciam o comportamento humano (Allport; Vernon; Lindzey, 1972). Eles interferem na constituição cognitiva e moral das percepções e juízos que orientam as ações humanas, incluindo os relacionamentos interpessoais, intra e intergrupais e com as instituições sociais e políticas (Schwartz; Bilsky, 1990), por isso são relevantes substratos simbólicos na constituição do ethos cultural das nações (Johnson, 1997).

É importante ressaltar que os valores são socialmente produzidos, da mesma forma que também são socialmente legitimados ou rejeitados (Manríquez, 2007;Viana, 2007). Na discussão sobre valores políticos, é fundamental a noção de socialização política, entendida como um processo permeado pelos valores e pelas disposições que contribuem para a constituição da identidade individual, em interface com os sistemas políticos, assim como em face das instituições (Oppo, 2000). Essa socialização compreende "os processos de transmissão e formação de opiniões, preferências, condutas e comportamentos em relação à política" (Tomizaki; Silva; Carvalho-Silva, 2016, p.931) que fazem parte da formação geral de todo ser humano. Dessa forma, a socialização política ocorre em variados espaços sociais e comunitários, sejam públicos, sejam privados, como a família, a escola, os movimentos estudantis, os movimentos sociais, além de instâncias como a mídia, os partidos políticos e o próprio parlamento, em função de suas variadas formas de mediação e de comunicação com a sociedade, incluindo o marketing político (Setton, 2005).

Os educadores também são agentes essenciais no processo de socialização política, tendo em vista que são portadores de valores políticos e também agentes de socialização política, ou seja, atuam na construção e na transmissão de valores e, consequentemente, de construção de subjetividades coletivas que dão forma à democracia (Ramos, 2000). A partir dessa perspectiva, este estudo foi realizado, por meio de um questionário com perguntas abertas e fechadas, com os educadores que atuam na Câmara dos Deputados 
e no Senado Federal, conforme detalhamento abaixo. A seguir, apresentamos uma breve contextualização das escolas do legislativo, com foco nas escolas da Câmara e do Senado.

\section{As escolas do legislativo e a educação para a democracia}

As escolas do legislativo no Brasil são recentes, criadas sob as possibilidades abertas pela Emenda Constitucional no 19, de 1998 (Messias Júnior, 2009). A pioneira foi a escola da Assembleia Legislativa do Estado de Minas Gerais (ALMG), criada antes dessa emenda, em 1992. A partir da iniciativa da ALMG, "várias outras casas legislativas do País, tanto em nível federal quanto estadual, passaram, especialmente nos últimos dez anos, a instituir, a ampliar e a consolidar as próprias escolas do legislativo" (Messias Júnior, 2009, p.85). Essa tendência foi intensificada com a criação da Associação Brasileira das Escolas do Legislativo (ABEL), em 2003. A ABEL reúne as escolas do legislativo federal, das assembleias estaduais, das câmaras municipais de vereadores e dos tribunais de contas da União, dos estados e municípios. Até o início do ano de 2018, havia cerca de 126 escolas do legislativo cadastradas, incluindo as federais, estaduais e 106 municipais, além dos tribunais de contas (Abel, 2018).

A literatura já registra algumas iniciativas internacionais de investimento dos parlamentos em educação legislativa. Entre os projetos mais estudados, destacam-se aqueles promovidos pelo parlamento escocês (Lloyd, 1984; Parry, 1997; Paterson, 1998; Allan, 2003). Também há pesquisas sobre os projetos educativos do parlamento britânico e do Parlamento Europeu (Leston-Bandeira, 2012), ao lado de estudos sobre os efeitos de programas de educação para a democracia desenvolvidos com o apoio de parlamentos de países como Quênia, Polônia, República Dominicana e África do Sul (Finkel;Smith, 2011). O Brasil também aparece nesse rol, especialmente nos estudos dos programas de educação política destinados à juventude (Fuks; Casalecchi, 2012; Fucks, 2014). Entretanto, há uma lacuna no que diz respeito às escolas do legislativo no Brasil.

No Brasil, essas escolas organizam suas atividades em duas frentes de atuação complementares. A primeira consiste na educação profissional de seus quadros funcionais, com cursos de formação política propriamente dita, além de cursos de aperfeiçoamento e de treinamentos para áreas específicas, como processo legislativo, gestão de programas institucionais, entre outros. A segunda compreende o letramento político propriamente dito por meio de projetos e programas de educação para a democracia, destinados a públicos externos, como visitantes e turistas, jovens, professores e entidades da sociedade civil, a exemplo dos vários projetos de simulação parlamentar desenvolvidos pelas assembleias legislativas estaduais e câmaras municipais (Cosson, 2008).

Conforme a análise de Marques Júnior (2009) e Ribeiro (2010), o crescente investimento das instituições legislativas em projetos de educação para a democracia é uma tentativa de resposta à crescente desconfiança política e à rejeição da população ao sistema representativo. Também as análises que tratam da educação para a democracia apontam 
que é pela formação cívica e política do cidadão que se desenvolvem as competências e apetências para a vida pública e a cultura cívica (Benevides, 1996).

O letramento político por meio do qual as escolas do legislativo desenvolvem seus programas de educação para democracia é definido por Cosson $(2015$, p. 81$)$ como "um processo de apropriação de práticas, conhecimentos e valores para a manutenção e o aprimoramento da democracia”. Apesar de essa definição se aproximar do conceito de socialização política, a gênese do letramento político vem dos processos intencionais e institucionais de educação voltados ao fortalecimento da cultura democrática (Martins, 2017).

A base desse conceito é proveniente de Bernard Crick (1998), que pretendeu diferenciar sua proposta da perspectiva conteudista dominante nas propostas de política da época. Assim, o conceito de letramento político passou a compreender "não apenas o conhecimento das instituições e ideias políticas e sociais, mas também as habilidades, os valores e atitudes que são necessários para a prática da boa cidadania na vida adulta" (Crick, 1998, p.64). O uso do termo se consagrou a partir do "Relatório Crick", o qual orientou as ações de letramento político no Reino Unido e se tornou um modelo para a Europa. Esse documento orienta a criação de um ambiente escolar no qual os alunos possam aprender a se tornar efetivos na vida pública, aliando a competência à apetência para a participação política. A proposta inclui uma metodologia voltada à discussão de problemas reais, considerando-se as instituições como meio para a resolução de problemas (Crick, 2002), tendo como fundamento valores de tolerância e respeito à diversidade de opiniões. Os conceitos de letramento político de Crick $(2002$; 2007) e de Cosson $(2011 ; 2015)$ se caracterizam como um aprendizado cultural que inclui, além de valores democráticos e conhecimentos sobre as instituições e processos políticos, o desenvolvimento de competências e habilidades para o engajamento e a participação política, sendo esses dois últimos termos associados à cidadania ativa.

Diferentemente de Almond e Verba (1989), que associam a cultura cívica a uma construção social de longo prazo, decorrente dos processos de modernização democrática, estudos em democracias recentes evidenciam que projetos institucionais de letramento político podem gerar alterações positivas em curto prazo (Finkel, 2003; Finkel; Smith, 2011). No Brasil, há uma variedade de pesquisas que se voltam principalmente para o exame dos efeitos de iniciativas de letramento político juvenil. A experiência mais estudada é a do Parlamento Jovem da ALMG (PJM), até por ser um dos projetos pioneiros do gênero no contexto nacional. A pesquisa de Gonçalves e Casalecchi (2013, p.73), por exemplo, tem como foco os impactos do PJM na confiança institucional. Fuks e Casalecchi (2012) ampliam o foco analítico, acrescentando ao rol temático da confiança o conhecimento sobre o funcionamento político da ALMG e os efeitos na imagem pública e na reputação da instituição, também com efeitos positivos. Estudos sobre o Parlamento Jovem Brasileiro (PJB), da Câmara dos Deputados (Carvalho, 2009), e o projeto Jovem Senador Brasileiro (PJS) (Oddone, 2015) apresentam conclusões similares quanto aos efeitos gerados acerca do aumento da atenção e do interesse dos egressos pela política, por meio do noticiário e da disposição para conversar sobre o tema com seus coetâneos, 
amigos e familiares. A pesquisa de Henrique (2013) sobre a visitação cívica ao Congresso Nacional também apresenta conclusões convergentes com as análises sobre os programas anteriormente mencionados.

\section{Os programas de educação para a democracia do Congresso Nacional}

Antes da análise dos dados da pesquisa, apresentamos uma breve contextualização sobre os órgãos que exercem a função de escolas do legislativo na Câmara e no Senado e uma descrição dos programas de educação para a democracia aqui estudados. Na Câmara, trata-se do Centro de Formação, Treinamento e Aperfeiçoamento (CEFOR) e, no Senado, o órgão equivalente é o Instituto Legislativo Brasileiro (ILB), criados em 1997. Ambos têm como atribuições "planejar e executar as atividades de formação, capacitação e letramento político, relacionadas à educação legislativa, bem como o recrutamento e a seleção de pessoal" (Carvalho, 2014, p. 54).

De acordo com a Coordenação para a Educação para a Democracia do Centro de Formação e Aperfeiçoamento da Câmara dos Deputados (CEFOR), a Câmara dos Deputados mantém 15 programas institucionais continuados de educação para a democracia, a maior parte deles elencados no Portal da Câmara, sob a aba "Programas Institucionais". 1 Já o Senado dispõe de um programa, conforme informação disponível no Portal do Senado. ${ }^{2}$ Desta forma, as duas casas mantêm atualmente 16 programas continuados de educação para a democracia, conforme mostra o Quadro 1.

Convém explicitar aqui que foram incluídos no Quadro 1 todos os programas de educação para a democracia mantidos continuadamente pelas duas instituições, independentemente do órgão responsável pelo seu gerenciamento. Em diversas instituições públicas e privadas, os programas educativos são desenvolvidos tanto pelas áreas de recursos humanos e de treinamento como também pelas áreas de marketing e de relações públicas, nas quais são considerados "ações de comunicação" e objetivam a difusão da "missão institucional" para a melhoria da percepção e da imagem da instituição. No caso do Congresso Nacional, a compreensão do papel institucional está diretamente ligada à educação para a cidadania. Nesse sentido, é importante ressaltar que nem todos são mantidos pelas escolas do legislativo em nível federal (CEFOR e ILB). No caso da Câmara dos Deputados, há programas considerados como de educomunicação e que, por isso, são gerenciados pela Secretaria de Comunicação (SECOM), como o Plenarinho e a Visitação.

Cabe ressaltar que o Programa de Visitas Monitoradas (Visitação Cívica) apresenta duas peculiaridades. Em primeiro lugar, é compartilhado pelas duas casas, já que as visitas são ao Palácio do Congresso Nacional. Em segundo lugar, a maior parte dos monitores das visitas (guias) é terceirizada e, portanto, não faz parte da amostra de educadores da

1 Disponível em: <http://www2.camara.leg.br/a-camara/programas-institucionais $>$. Acesso em: 16 jan. 2018.

2 Disponível em: <https://www12.senado.leg.br/jovemsenador>.Acesso: em 16 jan. 2018. 
democracia objeto do survey. Entretanto, esses monitores são treinados e gerenciados por uma equipe de servidores efetivos de cada instituição, responsável pela política de visitação cívica e pelas diretrizes educativas do referido programa. Muitos desses servidores também pertencem ao quadro de educadores das instituições. O programa, entretanto, é reconhecido pela literatura como "ferramenta de educação para a democracia" (Henrique, 2013, p. 373). Assim, a Câmara dos Deputados e o Senado Federal são responsáveis, respectivamente, por 92,85\% e 7,15\% dos programas constantes do Quadro 1.

Quadro 1 - Programas de educação para a democracia do Congresso Nacional

\begin{tabular}{|c|c|c|c|c|c|c|}
\hline Programas & Instituição & Início & $\begin{array}{l}\text { Periodi- } \\
\text { cidade }\end{array}$ & Duração & Público & Objetivos \\
\hline $\begin{array}{l}\text { Visitação } \\
\text { Cívica }\end{array}$ & $\begin{array}{l}\text { Câmara e } \\
\text { Senado }\end{array}$ & 1995 & Diária & $\begin{array}{l}30 \mathrm{mi}- \\
\text { nutos }\end{array}$ & $\begin{array}{l}\text { Turistas, visi- } \\
\text { tantes e estu- } \\
\text { dantes do DF }\end{array}$ & $\begin{array}{l}\text { Apresentações didáticas } \\
\text { sobre os espaços e as } \\
\text { funções das duas casas } \\
\text { do Congresso Nacional }\end{array}$ \\
\hline $\begin{array}{l}\text { Estágio- } \\
\text {-visita }\end{array}$ & Câmara & 2003 & Mensal & $\begin{array}{l}\text { Uma } \\
\text { semana }\end{array}$ & $\begin{array}{c}\text { Estudantes } \\
\text { universitários }\end{array}$ & $\begin{array}{l}\text { Oferecer palestras, de- } \\
\text { bates, visitas, vivências }\end{array}$ \\
\hline Politeia & $\begin{array}{l}\text { Câmara } \\
\text { e UnB }\end{array}$ & 2003 & Semestral & $\begin{array}{l}\text { Uma } \\
\text { semana }\end{array}$ & $\begin{array}{c}\text { Estudantes } \\
\text { universitários de } \\
\text { Ciência Política }\end{array}$ & $\begin{array}{l}\text { Oferecer palestras, de- } \\
\text { bates, visitas e vivências }\end{array}$ \\
\hline Plenarinho & Câmara & 2004 & Permanente & $\begin{array}{l}\text { Não se } \\
\text { aplica }\end{array}$ & $\begin{array}{c}\text { Crianças de } 7 \text { a } \\
14 \text { anos; profes- } \\
\text { sores da Edu- } \\
\text { cação Básica }\end{array}$ & $\begin{array}{c}\text { Oferecer jogos e } \\
\text { material didático } \\
\text { sobre temas políticos }\end{array}$ \\
\hline $\begin{array}{l}\text { Parlamen- } \\
\text { to Jovem }\end{array}$ & Câmara & 2004 & Anual & $\begin{array}{l}\text { Uma } \\
\text { semana }\end{array}$ & $\begin{array}{l}\text { Estudantes do } \\
\text { Ensino Médio }\end{array}$ & $\begin{array}{l}\text { Proporcionar vivência } \\
\text { do processo legislativo } \\
\text { por meio de simu- } \\
\text { lação parlamentar }\end{array}$ \\
\hline $\begin{array}{l}\text { Estágio } \\
\text { Cidadão }\end{array}$ & Câmara & 2004 & Mensal & $\begin{array}{l}\text { Uma } \\
\text { semana }\end{array}$ & $\begin{array}{l}\text { Estudantes uni- } \\
\text { versitários que } \\
\text { fazem estágio } \\
\text { na instituição }\end{array}$ & $\begin{array}{l}\text { Oferecer cursos e } \\
\text { palestras sobre pro- } \\
\text { cesso legislativo e } \\
\text { participação política }\end{array}$ \\
\hline $\begin{array}{l}\text { Estágio- } \\
\text {-partici- } \\
\text { pação }\end{array}$ & Câmara & 2005 & Mensal & $\begin{array}{l}\text { Uma } \\
\text { semana }\end{array}$ & $\begin{array}{c}\text { Estudantes } \\
\text { universitários }\end{array}$ & $\begin{array}{c}\text { Estimular a partici- } \\
\text { pação juvenil, com- } \\
\text { preendendo o papel } \\
\text { da instituição e o } \\
\text { processo legislativo }\end{array}$ \\
\hline $\begin{array}{l}\text { Câmara } \\
\text { Mirim }\end{array}$ & Câmara & 2006 & Mensal & Um dia & $\begin{array}{l}\text { Estudantes do } \\
\text { Ensino Fun- } \\
\text { damental }\end{array}$ & $\begin{array}{l}\text { Visitação guiada, } \\
\text { palestras e vivências } \\
\text { por meio de simu- } \\
\text { lação parlamentar }\end{array}$ \\
\hline
\end{tabular}




\begin{tabular}{|c|c|c|c|c|c|c|}
\hline $\begin{array}{l}\text { Escola na } \\
\text { Câmara }\end{array}$ & Câmara & 2008 & Mensal & Um dia & $\begin{array}{l}\text { Estudantes do } \\
\text { Ensino Médio }\end{array}$ & $\begin{array}{l}\text { Visitação guiada, } \\
\text { palestras e vivências } \\
\text { por meio de simu- } \\
\text { lação parlamentar }\end{array}$ \\
\hline $\begin{array}{l}\text { Eleitor } \\
\text { Mirim }\end{array}$ & Câmara & 2010 & Bienal & $\begin{array}{l}\text { Uma } \\
\text { semana }\end{array}$ & $\begin{array}{c}\text { Estudantes da } \\
\text { Educação Básica }\end{array}$ & $\begin{array}{l}\text { Simular campanha } \\
\text { eleitoral e debates }\end{array}$ \\
\hline $\begin{array}{c}\text { Missão } \\
\text { Pedagógica } \\
\text { no Parla- } \\
\text { mento }\end{array}$ & Câmara & 2011 & Anual & $\begin{array}{l}\text { Uma } \\
\text { semana }\end{array}$ & $\begin{array}{l}\text { Professores } \\
\text { da Educação } \\
\text { Básica das es- } \\
\text { colas públicas }\end{array}$ & $\begin{array}{l}\text { Visitação guiada, } \\
\text { palestras e elaboração } \\
\text { de projetos pedagó- } \\
\text { gicos sobre educação } \\
\text { para a democracia }\end{array}$ \\
\hline $\begin{array}{l}\text { Jovem } \\
\text { Senador }\end{array}$ & Senado & 2011 & Anual & $\begin{array}{l}\text { Uma } \\
\text { semana }\end{array}$ & $\begin{array}{l}\text { Estudantes do } \\
\text { Ensino Médio }\end{array}$ & $\begin{array}{l}\text { Proporcionar vivência } \\
\text { do processo legislativo } \\
\text { por meio de simu- } \\
\text { lação parlamentar }\end{array}$ \\
\hline $\begin{array}{l}\text { Oficina de } \\
\text { Atuação no } \\
\text { Parlamento }\end{array}$ & Câmara & 2014 & Semestral & $\begin{array}{c}\text { Uma } \\
\text { semana }\end{array}$ & $\begin{array}{l}\text { Representantes } \\
\text { de sociedade } \\
\text { civil organizada }\end{array}$ & $\begin{array}{l}\text { Oferecer conteú- } \\
\text { dos básicos sobre } \\
\text { como acompanhar } \\
\text { e participar do pro- } \\
\text { cesso legislativo }\end{array}$ \\
\hline $\begin{array}{l}\text { Seminá- } \\
\text { rios de } \\
\text { Interação } \\
\text { Legislativa }\end{array}$ & $\begin{array}{l}\text { Câmara e } \\
\text { Senado }\end{array}$ & 2014 & Anual & Um dia & $\begin{array}{l}\text { Servidores das } \\
\text { escolas dos legis- } \\
\text { lativos estaduais } \\
\text { e municipais }\end{array}$ & $\begin{array}{l}\text { Estreitar os vínculos } \\
\text { entre os legislativos } \\
\text { e proporcionar tro- } \\
\text { cas de experiências }\end{array}$ \\
\hline $\begin{array}{l}\text { Parlamen- } \\
\text { to para } \\
\text { Jornalistas }\end{array}$ & Câmara & 2015 & Semestral & Um dia & $\begin{array}{l}\text { Profissionais } \\
\text { de jornalismo }\end{array}$ & $\begin{array}{c}\text { Disseminar infor- } \\
\text { mações sobre o } \\
\text { Poder Legislativo }\end{array}$ \\
\hline $\begin{array}{c}\text { Escola } \\
\text { Virtual de } \\
\text { Cidadania }\end{array}$ & Câmara & 2015 & Permanente & $\begin{array}{l}\text { Não se } \\
\text { aplica }\end{array}$ & $\begin{array}{l}\text { Todos os pú- } \\
\text { blicos inte- } \\
\text { ressados em } \\
\text { educação para } \\
\text { a democracia }\end{array}$ & $\begin{array}{l}\text { Oferecer cursos pre- } \\
\text { senciais e on-line sobre } \\
\text { temas relacionados às } \\
\text { funções e à atuação } \\
\text { do Poder Legislativo }\end{array}$ \\
\hline
\end{tabular}

Fonte: Elaboração própria, com base em informações fornecidas por meio de entrevistas presenciais com os coordenadores dos referidos programas, em janeiro de 2018, em Brasília, na sede do CEFOR.

O Quadro 2 apresenta um panorama da situação dos educadores das duas casas, com um total de 795 servidores, sendo 578 do sexo masculino e 217 do sexo feminino. A Câmara conta com um quadro de 621 servidores que atuam nos programas de educação para a democracia e o Senado com 174, ambos com predomínio de educadores do sexo masculino $(71,98 \%$ e $75,30 \%$, respectivamente). É oportuno esclarecer que este quadro inclui todos os servidores que atuam de alguma forma nos programas mencionados no Quadro 1. Entretanto, não se trata de dedicação exclusiva aos programas. Ambas as casas operam com a seguinte sistemática: os servidores são lotados em órgãos específicos das duas instituições e atuam nos programas como atividade complementar, ou seja, além das 
atividades para as quais foram efetivados. $\mathrm{O}$ recrutamento para os projetos de educação para a democracia se dá em função da experiência prévia dos servidores com educação e áreas afins, como psicologia, sociologia, ciência política e outras.

Quadro 2 - Educadores do Congresso Nacional que atuam nos programas de educação para a democracia

\begin{tabular}{c|c|c|c|c|c|c}
\hline \multicolumn{2}{c}{ INSTITUIÇÃO } & \multicolumn{1}{c}{ TOTAL } & \multicolumn{2}{c}{ MASC - N } & \multicolumn{1}{c}{ MASC - \% } & \multicolumn{2}{c}{ FEM - N } & \multicolumn{2}{c}{ FEM - \% } & Total \\
\hline Câmara & 621 & 447 & 71,98 & 174 & 28,02 & 100 \\
\hline Senado & 174 & 131 & 75,30 & 43 & 24,70 & 100 \\
\hline Total & 795 & 578 & ------ & 217 & -------- & ----- \\
\hline
\end{tabular}

Fonte: Elaboração do autor, com dados da Câmara dos Deputados (Coordenação de Pesquisa do Centro de Documentação e Informação) e do Senado Federal (Secretaria de Transparência), 2017.

A pesquisa contempla $25,75 \%$ do quadro de educadores da Câmara e $39,65 \%$ do Senado, como mostra o Quadro 3.

Quadro 3 - Respondentes por instituição

\begin{tabular}{|c|c|c|c|c|c|c|}
\hline INSTITUIÇÃO & $\begin{array}{c}\text { MASC } \\
-\mathbf{N}\end{array}$ & $\begin{array}{c}\text { MASC } \\
-\%\end{array}$ & $\begin{array}{l}\text { FEM } \\
-\mathbf{N}\end{array}$ & $\begin{array}{c}\text { FEM- } \\
\%\end{array}$ & TOTAL-N & $\begin{array}{c}\text { TOTAL } \\
\%\end{array}$ \\
\hline Câmara & 215 & 70 & 92 & 30 & 307 & 25,75 \\
\hline Senado & 113 & 75,3 & 37 & 24,7 & 151 & 39.65 \\
\hline Total & 328 & --- & 129 & --- & 458 & --- \\
\hline
\end{tabular}

Fonte: Elaboração do autor, com dados da Câmara e do Senado, 2017.

\section{Estratégias metodológicas}

O foco do estudo é a análise dos valores políticos dos agentes de educação para a democracia do Congresso Nacional. O objetivo é avaliar os valores desse grupo a partir de suas próprias percepções. Para tanto, foi aplicado um questionário eletrônico com perguntas abertas e fechadas. O foco do questionário foi a adesão desses servidores a um elenco de valores políticos, tais como igualdade de direitos, tolerância política, respeito à diferença e à diversidade cultural e sexual, novas configurações familiares, participação política e social, voto obrigatório, entre outros. Esse conjunto de questões foi selecionado em função de estudos similares utilizados para a análise de valores políticos, com adaptações ao objeto em tela. ${ }^{3}$ De forma complementar, foram realizadas cinco entrevistas com os gestores dos programas de educação para a democracia das duas instituições, em janeiro de 2018.

A pesquisa foi realizada no período de $1^{\circ}$ a 30 de abril de 2017. O questionário foi enviado aos 795 servidores da Câmara dos Deputados e do Senado Federal que atuam como agentes pedagógicos nos 15 programas continuados de educação para a democracia, com (2006); Lima; Cheibub (1996), com adaptações. 
respostas espontâneas. O questionário foi formatado no padrão do Google Forms, cujo link foi enviado diretamente aos educadores, por e-mail. Juntamente com o link foi enviada uma carta de apresentação dos pesquisadores, com os objetivos da pesquisa. Os websurveys estão sendo largamente utilizados, devido à facilidade de alcance das pessoas a serem inquiridas. Já são reconhecidos na literatura como um instrumento importante para o acesso a pessoas distantes, como no caso da pesquisa em questão (Manfreda;Vehovar, 2008).

\section{Perfil dos respondentes}

O grupo de respondentes é composto por 30\% e 24,70\% de mulheres, na Câmara e no Senado, respectivamente. O intervalo etário predominante nas duas casas varia de 41 a 60 anos, revelando um grupo maduro, o que justifica a elevada escolaridade, com 67,80\% de servidores com pós-graduação stricto sensu na Câmara e 71,30\% no Senado. A maioria apresenta de 6 a 15 anos de tempo de serviço nas duas instituições. A área administrativa apresenta um maior efetivo na Câmara (56,50\%), enquanto no Senado o maior está na área legislativa (54,10\%). O número de servidores filiados a partidos políticos é inexpressivo nas duas casas: 4\% na Câmara e 5,40\% no Senado. No grupo da Câmara, os partidos mais citados foram PV, com três menções; PT e PCO, com duas menções, e os seguintes com apenas uma menção: PR, PSOL e PSB. No Senado, o PV também recebeu três citações; o PT e PSOL, duas, e a Rede, uma.

Quadro 4 - Perfil dos respondentes

\begin{tabular}{l|c|c}
\hline \multicolumn{1}{l}{ SEXO } & CÂMARA - $\%$ & \multicolumn{1}{c}{ SENADO - $\%$} \\
\hline Feminino & 30 & 24,7 \\
\hline Masculino & 70 & 75,3 \\
\hline FAIXA ETÁRIA & 1,3 & 2 \\
\hline Até 30 anos & 15,3 & 19,3 \\
\hline 31 a 40 anos & 40,4 & 40,7 \\
\hline 41 a 50 anos & 41,7 & 37,3 \\
\hline 51 a 60 anos & 1,3 & 0,7 \\
\hline Acima de 60 & & \\
\hline TEMPO DE SERVIÇO NA CASA & 3,9 & 14 \\
\hline Até 5 anos & 23,9 & 24 \\
\hline 6 a 10 anos & 34,3 & 33,3 \\
\hline 11 a 15 anos & 28,1 & 20,7 \\
\hline 16 a 20 anos & 9,8 & 8 \\
\hline Acima de 20 anos & & \\
\hline TEMPO DE ATUAÇÃO NOS PROJETOS DE EDUCAÇÃO & 27,9 & 40,3 \\
\hline Até 5 anos & 41,6 & 32,9 \\
\hline 6 a 10 anos & 25,5 & 20,1 \\
\hline 11 a 15 anos & & \\
\hline
\end{tabular}




\begin{tabular}{l|c|c}
\hline 16 a 20 anos & 3 & 4,7 \\
\hline Acima de 20 anos & 2 & 2 \\
\hline ESCOLARIDADE & 100 & 100 \\
\hline Curso superior & 2,9 & 3,4 \\
\hline Especialização & 23,8 & 22 \\
\hline Mestrado & 41,7 & 42 \\
\hline Doutorado & 26,1 & 29,3 \\
\hline Pós-doutorado & 5,5 & 3,3 \\
\hline 1SETOR DE ATUAÇÃO & & \\
\hline Administrativa & 56,5 & 45,9 \\
\hline Legislativa & 43,5 & 54,1 \\
\hline FILIAÇÃO PARTIDÁRIA & & \\
\hline Sim & 4 & 5,4 \\
\hline Não & 96 & 94,6 \\
\hline
\end{tabular}

Fonte: Elaboração própria. ${ }^{4}$

\section{Análise e discussão dos dados}

Indagados sobre a situação da democracia brasileira nas últimas décadas, as respostas dos dois grupos são relativamente similares entre os servidores da Câmara dos Deputados e do Senado Federal, em todos os tópicos, com predomínio da opinião de que houve pouco avanço $(50,80 \%$ e $46,00 \%$, respectivamente) e de que avançou muito $(34,90 \%$ e $34,70 \%$ ), como se lê na Tabela 1. Entre os argumentos apontados para justificar que avançou pouco, destacam-se constatações recorrentes de que "ainda há muito para a consolidação democrática no País, especialmente no que se refere à participação social e aos direitos civis e sociais". Outro argumento citado com frequência pelos respondentes foi o que de "a nossa democracia ainda é incompleta por causa da grande desigualdade social que impede a plena cidadania, gerando um grande contingente de excluídos e de subcidadãos". $\mathrm{O}$ terceiro argumento acionado pelos informantes diz respeito à "baixa qualidade dos serviços públicos oferecidos pelo Estado, o que prejudica especialmente os menos favorecidos".

Quanto aos que concordam que a democracia avançou muito, os aspectos considerados se referem principalmente à democracia representativa e à organização institucional, "com eleições livres, separação dos poderes e funcionamento autônomo das

4 A lotação é importante porque os servidores da área legislativa exercem funções distintas daqueles da área administrativa. Enquanto os primeiros se ocupam de questões atinentes ao processo legislativo, às atividades das comissões e dos demais órgãos da atividade-fim da instituição, os da área administrativa exercem funções do campo denominado de atividade-meio, que podem servir de suporte à atividade legislativa, mas não são diretamente relacionadas ao processo legislativo. Nesse sentido, a atuação do servidor é relevante, pois cada um atua nos programas de educação para a democracia de acordo com suas competências e experiências. 
instituições políticas". A estagnação é apontada como "consequência das sucessivas crises políticas, escândalos e disputas de poder que afetam a governabilidade e impedem o avanço democrático". Os poucos que apontaram retrocessos não apresentaram argumentos para justificar suas opiniões.

Tabela 1 - Na sua opinião, nas últimas décadas, a democracia brasileira:

\begin{tabular}{c|c|c}
\hline RESPOSTAS & \multicolumn{1}{c}{ CÂMARA } & SENADO \\
\hline Avançou muito & $34,90 \%$ & $34,70 \%$ \\
\hline Avançou pouco & $50,80 \%$ & $46,00 \%$ \\
\hline Estagnou & $10,70 \%$ & $10,70 \%$ \\
\hline Retrocedeu pouco & $2,60 \%$ & $6,70 \%$ \\
\hline Retrocedeu muito & $2,60 \%$ & $2,00 \%$ \\
\hline Total & 100,00 & 100,00 \\
\hline
\end{tabular}

Fonte: Elaboração própria.

A relativa similaridade nas opiniões se repete no tópico sobre o combate à corrupção política, predominando a avaliação de que o país avançou pouco nesse quesito (50,30\% e 44\%), entre os respondentes da Câmara e do Senado, respectivamente, como mostra a Tabela 2. As justificativas predominantes dizem respeito à "grande sensação de impunidade que ainda reina no país", além de "um combate seletivo, partidarizado, deixando vários corruptos incólumes, que sequer são investigados". Os que acham que avançou muito argumentam que "a investigação e até mesmo a prisão de figuras importantes do mundo político e do setor empresarial se confirma como um marco no combate à corrupção no Brasil, algo nunca visto no passado". Os que acham que estagnou justificam que "os processos são muito lentos, deixando muitos políticos corruptos em postos importantes, inclusive no comando de instituições como o Senado e alguns ministérios". Os que pensam que retrocedeu afirmam que "o combate à corrupção não pode se confundir com perseguição política para punir somente a esquerda".

Tanto as percepções sobre o estágio atual da democracia quanto em relação à corrupção são pertinentes, pois expressam valores e crenças a respeito do regime e dos mecanismos de controle da corrupção. Nesse sentido, as respostas demonstram uma expectativa elevada dos informantes tanto no que se refere ao avanço da democracia quanto ao combate à corrupção. 
Tabela 2 - Quanto ao combate à corrupção nas últimas décadas, você acha que o Brasil:

\begin{tabular}{c|c|c}
\hline RESPOSTAS & \multicolumn{1}{c}{ CÂMARA } & SENADO \\
\hline Avançou muito & $29,10 \%$ & $36,00 \%$ \\
\hline Avançou pouco & $50,30 \%$ & $44,00 \%$ \\
\hline Estagnou & $16,30 \%$ & $12,00 \%$ \\
\hline $\begin{array}{c}\text { Retrocedeu } \\
\text { pouco }\end{array}$ & $3,30 \%$ & $6,70 \%$ \\
\hline $\begin{array}{c}\text { Retrocedeu } \\
\text { muito }\end{array}$ & $1,00 \%$ & $1,30 \%$ \\
\hline Total & 100,00 & 100,00 \\
\hline
\end{tabular}

Fonte: Elaboração própria.

Outra questão relevante do ponto de vista dos valores políticos é a percepção sobre o voto do conjunto dos cidadãos. Afinal, em um regime democrático, todo voto tem o mesmo peso, apagando, em tese, as hierarquias sociais e econômicas. Tal concepção de hierarquias sociais, contudo, pode permanecer na opinião dos informantes. Quanto a isso, predomina a concepção de que esses eleitores não sabem votar $(63,90 \%$ e 63,50\%, respectivamente), contra a percepção de 34,70\% e 30,60\%, entre os respondentes da Câmara dos Deputados e do Senado Federal, respectivamente, de que a maioria dos eleitores vota de vez em quando de forma consciente e apenas 1,40\% e 5,90\% que acham que o voto é sempre consciente (Tabela 3). Para os que responderam que a maioria dos eleitores não sabe votar, os argumentos são categóricos, resumidos nos seguintes relatos:

- Se soubessem votar, não teríamos os políticos que temos.

- A crise política que devasta o país é exatamente porque os brasileiros não sabem votar.

- Falta maturidade política à maioria dos eleitores.

Os informantes que acham que a maioria dos eleitores vota de vez em quando de forma consciente justificam que

temos uma cultura política de ocasião, ou seja, total casuística e oportunista, o que leva os eleitores às vezes a refletirem bem sobre suas opções eleitorais e outras vez a votarem por impulso, movidos mais pela emoção e pelos fatores da conjuntura, do momento da eleição, sem uma visão de médio e longo prazos.

O segmento minoritário cuja opinião é de que o voto é sempre consciente usou como base sua própria experiência de eleitor:"eu sempre voto de forma muito criteriosa, pesando com cuidado os prós e os contra, o que me leva a supor que esse seja o padrão do voto do brasileiro, já que eu também sou brasileiro”.

Como visto, predominam as percepções que valorizam a sua própria postura perante o voto, enquanto desqualificam a postura de terceiros, um comportamento similar ao 
denominado efeito de terceira pessoa (Davison,1983). Segundo essa perspectiva, os indivíduos tendem a avaliar de forma depreciativa a opinião dos outros, enquanto se excluem desse enquadramento, como se apenas os outros fossem desatentos e irresponsáveis com o voto. Trata-se de uma forma de valorar positivamente a sua conduta política, enquanto desvaloriza a conduta dos demais.

Tabela 3 - Na sua opinião, a maioria dos eleitores brasileiros:

\begin{tabular}{c|c|c}
\hline RESPOSTAS & CÂMARA & SENADO \\
\hline Vota sempre de forma consciente & $1,40 \%$ & $5,90 \%$ \\
\hline Vota de vez quando de forma consciente & $34,70 \%$ & $30,60 \%$ \\
\hline Não sabe votar & $63,90 \%$ & $63,50 \%$ \\
\hline Total & 100,00 & 100,00 \\
\hline
\end{tabular}

Fonte: Elaboração própria.

Quanto ao papel dos partidos políticos na democracia brasileira, prevalece a opinião de que são totalmente necessários, com mais de $80 \%$, como expresso na Tabela 8 , sustentada por argumentos sobre a função formal das legendas:

- Uma democracia sem partidos é algo inimaginável.

- Querendo ou não, os partidos são a alma da democracia representativa.

- Sem partidos não é possível nem fazer eleições.

- A escolha dos representantes passa necessariamente pela via partidária.

Os informantes que acham que os partidos políticos são pouco necessários reconhecem a função formal das legendas, mas contra-argumentam que "mesmo sendo indispensáveis no sistema representativo, no caso específico do Brasil, os partidos são pouco relevantes do ponto de vista da efetividade política". Outro respondente complementa que "os partidos são ambíguos, pois, ao mesmo tempo em que são os mediadores por excelência da democracia representativa, são também os grandes operadores da corrupção política”. Em relação ao segmento minoritário que assinalou que as legendas são totalmente desnecessárias, houve apenas o seguinte argumento: "trabalho no Congresso e lido com educação para a democracia, mas está cada vez mais difícil sustentar a tese da relevância do papel dos partidos, pois estão se tornando agremiações para institucionalizar a corrupção no País”.

Avaliar a percepção sobre o papel dos partidos no regime democrático também é uma forma de medir valores políticos, pois a avaliação sobre os partidos é uma medida de reputação política. Os percentuais de respostas expostos na Tabela 4 certamente se explicam pelo fato de que se trata de um público com informação privilegiada em relação ao Poder Legislativo, um segmento que compreende as funções dos partidos, apesar das ressalvas feitas. Outra observação é que a pergunta se refere especificamente à necessidade dos partidos e não à atuação das legendas nem à confiança dos respondentes. 
Tabela 4 - Quanto ao papel dos partidos políticos na democracia brasileira, você acha que:

\begin{tabular}{c|c|c}
\hline RESPOSTAS & CÂMARA & SENADO \\
\hline São totalmente necessários & 84,50 & 88,00 \\
\hline São pouco necessários & 12,50 & 11,30 \\
\hline São totalmente desnecessários & 3,00 & 0,70 \\
\hline Total & 100,00 & 100,00 \\
\hline
\end{tabular}

Fonte: Elaboração própria.

Acerca das políticas igualitárias, como exibido na Tabela 5, prevalece um consenso dos respondentes a favor de tais políticas, com 70\% em ambos os grupos, sem nenhum registro relativo à opção “Não concordo com nenhuma”. A dispersão de respostas distribuídas em alguns itens específicos parece indicar prioridades dos respondentes e não discordância em relação ao conjunto dos direitos, o que se deduz pelos dados já mencionados. Entre os argumentos apontados, destaca-se o seguinte:

Um aspecto muito importante, que serve de base da democracia, é o pressuposto da igualdade perante a lei. Portanto, como educador e como militante dos projetos de educação para a democracia, defendo sempre que nunca deve haver restrição de direitos, seja para quem for, seja homem, mulher, gay, negro, índio, religioso ou não, trabalhador ou empresário.

Do ponto de vista das políticas igualitárias, portanto, o que se observa é que os educadores reconhecem a igualdade como um valor essencial à democracia. A relação entre democracia e igualdade tem sido discutida na literatura como um dos eixos dos estudos contemporâneos nas ciências sociais, apontando para a necessidade de avanços no sentido de transcender a discussão sobre igualdade formal e abraçar propostas de igualdade material. Trata-se de uma perspectiva que já conquistou apoio até das elites políticas, implicando a construção de uma espécie de "novo consenso da sociedade brasileira" (Balbachevsky; Holzhacker, 2011) .

A dimensão igualitária da democracia é cada vez mais considerada nas análises contemporâneas. O princípio igualitário salienta que "os direitos políticos e liberdades civis formais são insuficientes para a igualdade política” (Coppedge; Gerring; Lindberg, 2012, p.100). Por essa razão, os sistemas de governo instituídos pela democracia eleitoral devem considerar em suas políticas os fatores materiais e imateriais que causam desigualdades e inibem o exercício efetivo dos direitos e das liberdades civis. Assim, grupos definidos conforme renda, instrução, etnia, religião, casta, raça, língua, região, gênero e identidade “devem usufruir do mesmo nível de participação, representação, poder de formação de agenda, proteção perante a lei e influência no desenho e implementação de políticas institucionais" (Coppedge; Gerring; Lindberg, 2012, p.100). 
Tabela 5 - Com quais das políticas de direitos igualitários você concorda?

RESPOSTAS CÂMARA SENADO

\begin{tabular}{|c|c|c|}
\hline Igualdade de direitos entre homens e mulheres & $6,1 \%$ & $6 \%$ \\
\hline Igualdade de direitos entre brancos, negros e indígenas & $5,3 \%$ & $6 \%$ \\
\hline $\begin{array}{l}\text { Igualdade de direitos entre heterossexuais, } \\
\text { homossexuais, bissexuais e transgêneros }\end{array}$ & $4,2 \%$ & $5,3 \%$ \\
\hline Igualdade de direitos entre pessoas de diferentes religiões & $7,1 \%$ & $6 \%$ \\
\hline Igualdade de direitos entre trabalhadores domésticos e dos demais setores & $5,4 \%$ & $4 \%$ \\
\hline Concordo com todas & $71,9 \%$ & $72,7 \%$ \\
\hline Não concordo com nenhuma & $0 \%$ & $0 \%$ \\
\hline TOTAL & 100 & 100 \\
\hline
\end{tabular}

Fonte: Elaboração própria.

A mesma linha de raciocínio prevalece quando indagados especificamente sobre os direitos das famílias, uma das questões que têm mobilizado a opinião pública em função da proposta do Estatuto da Família ${ }^{5}$, que tem como objetivo definir o conceito de família. Como mostra a Tabela 6, 91,10\% dos educadores da Câmara responderam que todos os tipos de família devem ser tratados de forma igualitária perante a lei, enquanto no Senado o percentual de repostas foi de 79,70\%. Os argumentos acionados para sustentar essa perspectiva foram os seguintes:

- É uma questão crucial no Estado de Direito: a igualdade.

- O conceito de família ampliou-se e o direito deve alcançar todos e todas sem distinção alguma.

- Vejo casamento e uniões estáveis como contratos e, portanto, com direitos jurídicos, pois se trata de uma sociedade.

- A família é uma construção social.Assim, deve mudar conforme a sociedade muda.

Os poucos que argumentaram de forma contrária usaram como justificativa motivos morais e religiosos, sintetizados nos seguintes relatos:

- Família a que me refiro aqui é a natural. O seu conceito é exclusivo, não admite sua origem fora do casal.

- A família tem como natureza o papel de um pai e de uma mãe, não queiramos agora reinventar a roda.

5 Trata-se do Projeto de Lei 6583/2013, de autoria do deputado Anderson Ferreira (PR/PE), que define o conceito de família como "a entidade familiar formada a partir da união entre um homem e uma mulher, por meio de casamento ou de união estável, e a comunidade formada por qualquer dos pais e seus filhos". 
A percepção da igualdade como valor se confirma na questão específica sobre o direito das famílias. Embora estejamos no campo da igualdade formal, cabe uma reflexão sobre a relação entre família, igualdade e democracia. Dessa perspectiva, a família é uma construção social e histórica, a qual passa por rearranjos em função de influências da sociedade e da cultura. Como toda construção sócio-histórica é dinâmica, a família, igualmente, passa por esse dinamismo, o que implica atualizações de seu estatuto formal e jurídico, como argumenta Linda Manuel:

a família como berço, paradigma, chave hermenêutica e horizonte de significação de uma democracia sempre a aperfeiçoar e a desenvolver, qual tarefa jamais consumada (1995, p.97).

Tabela 6 - Em relação aos direitos das famílias, qual sua opinião?

\begin{tabular}{|c|c|c|}
\hline RESPOSTAS & CÂMARA & SENADO \\
\hline Todos os tipos de família devem ser tratados de forma igualitária perante a lei & $91,10 \%$ & $79,70 \%$ \\
\hline $\begin{array}{l}\text { A família que merece proteção do Estado é somente } \\
\text { aquela formada por um homem e uma mulher }\end{array}$ & $3,60 \%$ & $8,80 \%$ \\
\hline Não tenho opinião formada & $5,30 \%$ & $11,50 \%$ \\
\hline Total & $100,00 \%$ & $100,00 \%$ \\
\hline
\end{tabular}

Fonte: Elaboração própria.

Os informantes revelam-se amplamente favoráveis às modalidades de participação cidadã tanto no plano institucional como não institucional ${ }^{6}$, conforme se lê nas Tabelas 7 e 8 . Do ponto de vista argumentativo, não houve distinção quanto às duas modalidades de participação, como se pode observar nos seguintes relatos:

- A participação é cada vez mais importante nas democracias, seja pelas vias institucionais, seja por outros meios, até mesmo boicotes e protestos.

- Toda forma de manifestação do cidadão é legítima e deve ser valorizada e considerada pelo Estado.

6 Usamos aqui a tipologia de Borba (2012), segundo a qual a participação institucional está diretamente relacionada com a esfera estatal, enquanto a participação não institucional estaria na esfera extraestatal. 
Tabela 7 - Acerca das formas de participação política e social na esfera institucional, com quais você concorda?

\begin{tabular}{c|c|c}
\hline RESPOSTAS & CÂMARA & \multicolumn{1}{c}{ SENADO } \\
\hline Plebiscitos & $2,1 \%$ & $1,3 \%$ \\
\hline Referendos & $1,7 \%$ & $1,1 \%$ \\
\hline Conselhos gestores setoriais (educação, saúde, juventude, etc.) & $2,8 \%$ & $2,1 \%$ \\
\hline Conferências nacionais setoriais (educação, saúde, juventude, etc.) & $2,6 \%$ & $1,3 \%$ \\
\hline Orçamento participativo & $3,7 \%$ & $3,1 \%$ \\
\hline Consultas públicas on-line & $1,2 \%$ & $3,2 \%$ \\
\hline Audiências públicas on-line & $2,2 \%$ & $2,3 \%$ \\
\hline Petições on-line & $1,8 \%$ & $1,7 \%$ \\
\hline Apoio todos & $81,9 \%$ & $83,9 \%$ \\
\hline Não apoio nenhum & $0 \%$ & $0 \%$ \\
\hline Sou indiferente & $0 \%$ & $0 \%$ \\
\hline Total & 100 & 100 \\
\hline
\end{tabular}

Fonte: Elaboração própria.

Comparando as duas tabelas sobre participação, observa-se que os informantes tendem a considerar a participação política um valor no regime democrático sem distinções expressivas quanto à modalidade de participação - se institucional ou não. Dito de outra forma, as visões dos respondentes expressam a superação da antinomia entre a representação política liberal e a participação democrática.A concepção de uma relação não dicotômica entre representação e participação tem como base uma visão da representação que vai além de uma simples autorização ou consentimento popular mediante o voto. Nessa perspectiva, a participação é vista como constituinte da representação e esta depende daquela para se legitimar e produzir accountability (Lavalle;Vera, 2011).

Tabela 8 - Quanto às formas de participação não institucional, com quais você concorda?

\begin{tabular}{c|c|c}
\hline RESPOSTAS & CÂMARA & SENADO \\
\hline Greves & $2,1 \%$ & $1,7 \%$ \\
\hline Boicotes & $1,3 \%$ & $2,1 \%$ \\
\hline Protestos & $3,6 \%$ & $2,7 \%$ \\
\hline Abaixo-assinados & $2,2 \%$ & $3,2 \%$ \\
\hline Passeatas & $2 \%$ & $1,8 \%$ \\
\hline Petições & $2 \%$ & $2,7 \%$ \\
\hline Ativismo digital & $4,1 \%$ & $5,7 \%$ \\
\hline Apoio todos & $82,7 \%$ & $80,1 \%$ \\
\hline Não apoio nenhum & $0 \%$ & $0 \%$ \\
\hline Sou indiferente & $0 \%$ & $0 \%$ \\
\hline Total & 100 & 100 \\
\hline
\end{tabular}

Fonte: Elaboração própria. 
Em termos de perfil ideológico, há um predomínio de informantes que se autodeclaram como de esquerda, centro e "não me enquadro em nenhuma", como mostra a Tabela 9. Não há registros expressivos de educadores nos extremos do espectro ideológico-partidário, ou seja, nem extrema-direita nem extrema-esquerda. Considerando efetivamente os registros que se enquadram na classificação convencional, há uma leve diferença entre o perfil dos respondentes da Câmara e do Senado. No primeiro caso, prevalece quem se considera esquerda (37,20\%); no Senado, a preponderância é de centro (30,70\%).

Os que se identificam com a esquerda justificam que:

- O projeto da esquerda ainda é o mais democrático, o mais republicano e o mais inclusivo.

- Grande parte dos avanços democráticos no Brasil nas últimas décadas se deve à atuação política da esquerda.

Entre os argumentos destacados pelos de centro destacam-se os seguintes:

- Não sou adepto de radicalismos, por isso não simpatizo nem com a esquerda, nem com a direita.

- Acho que os partidos de centro são mais flexíveis e mais realistas do que os de direita e os de esquerda.

Embora a discussão sobre o espectro ideológico seja questionável, principalmente no que se refere à polarização entre direita e esquerda e suas variações, trata-se de uma classificação ainda muito utilizada (Tarouco; Madeira, 2013; Scheeffer, 2014). Cabe frisar ainda que a pesquisa solicitava aos educadores que se autodenominassem, ou seja, na prática indagava como eles se percebem, em termos de posicionamento no espectro ideológico-partidário, com predomínio de respostas relativas ao centro e à esquerda. Convencionalmente, o centro é visto como um lugar intermediário, enquanto a esquerda "representa o conjunto de forças que luta, essencialmente, por transformações que resultem na instauração de uma ordem diferente da capitalista, ou transformações que resultem em uma reformulação substancial da mesma" (Scheeffer, 2014, p. 4). A esquerda se define em oposição à direita, entendida como o eixo ideológico constituído pelas "forças favoráveis à manutenção da ordem social e política. A direita se preocupa, basicamente, em conservar e não alterar o sistema que está dado" (Scheeffer, 2014, p. 4). 
Tabela 9 - Em termos políticos você se considera:

\begin{tabular}{|c|c|c|}
\hline RESPOSTAS & CÂMARA & SENADO \\
\hline Extrema direita & $0,00 \%$ & $0,00 \%$ \\
\hline Direita & $3,50 \%$ & $3,30 \%$ \\
\hline Centro-direita & $4,60 \%$ & $2,00 \%$ \\
\hline Centro & $19,40 \%$ & $30,70 \%$ \\
\hline Centro-esquerda & $6,80 \%$ & $10,00 \%$ \\
\hline Esquerda & $37,20 \%$ & $29,30 \%$ \\
\hline Extrema-esquerda & $3,50 \%$ & $0,00 \%$ \\
\hline Não me enquadro em nenhuma & $25,00 \%$ & $24,70 \%$ \\
\hline TOTAL & 100,00 & 100,00 \\
\hline
\end{tabular}

Fonte: Elaboração própria.

$\mathrm{Na}$ parte relacionada à avaliação da contribuição das instituições, há diferenças expressivas entre os informantes das duas casas, considerando a média ponderada das respostas, numa escala de zero a cinco, sendo cinco a nota máxima, conforme exposto no Gráfico 1. No caso dos respondentes da Câmara, as notas mais elevadas foram para os sindicatos (4,67\%), a imprensa (4,62\%), o Poder Judiciário (3,85\%), o Poder Executivo $(3,79 \%)$ e o Congresso Nacional $(3,65 \%)$, com a ressalva de que o Congresso Nacional figura em quinto lugar nessa escala. No caso dos servidores do Senado, o ranking é o seguinte: em primeiro lugar, o Poder Judiciário (2,26\%) e os seguintes em segundo lugar, empatados: imprensa (2,24\%), Poder Executivo (2,24\%) e Congresso Nacional (2,24\%). Chama atenção que o Congresso Nacional também não fica em primeiro lugar.

Outro aspecto a ser destacado é a baixa avaliação para instituições como as organizações não-governamentais (ONGs) e os movimentos sociais. Ressalta-se, entretanto, que instituições como imprensa e sindicatos são bem avaliadas, ao contrário das ONGs e dos movimentos sociais. 
Gráfico 1 - Quais as contribuições das instituições abaixo para a democracia brasileira?

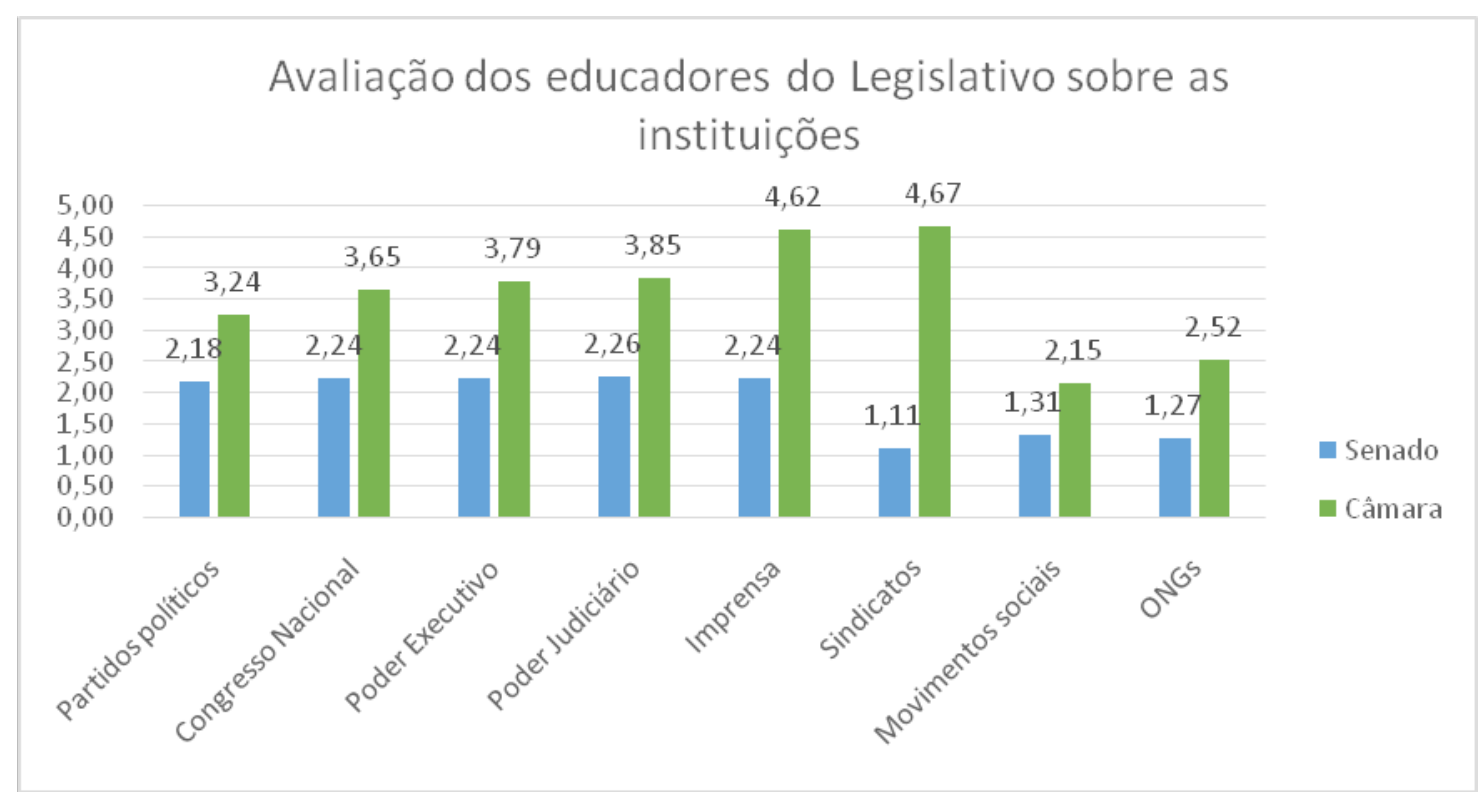

Fonte: Elaboração própria.

Consultados sobre as opiniões que deveriam ser levadas em conta na propositura de novas leis ou na alteração da legislação já existente, a maioria dos educadores optou pela resposta "todas as alternativas", como mostra a Tabela 10. Isso implica levar em conta a opinião de especialistas sobre o tema das leis, a opinião dos partidos políticos, a opinião de sindicatos, associações e entidades que representam aqueles que serão diretamente afetados pelas leis e a opinião da maioria da população. Nas justificativas, os argumentos apresentados foram os seguintes:

- Lei é algo muito sério e não deve ser proposta, aprovada ou alterada pela simples vontade individual do legislador, mas deve ser algo o mais democrático possível.

- Uma das razões porque as leis brasileiras "não pegam” é que elas não são amplamente debatidas.

- Numa democracia não há mais espaço para leis feitas de forma autoritária e unilateral.

Os depoimentos revelam uma visão dos educadores alinhada com a noção de lei como uma ligação entre representantes e representados, algo próximo da perspectiva acima apontada no tópico sobre a relação convergente entre representação e participação. Trata-se de uma perspectiva de lei como lex (ligação), que remete ao ideário republicano defendido por Hannah Arendt (2004). Segundo essa perspectiva, a lei corporifica a vontade de uma comunidade política, em torno de um consenso, fruto do compartilhamento de valores "que são aceitos coletivamente e assumidos como necessários para regular a conduta de cada cidadão em nome de algo maior: a democracia" (Barros, 2016, p.870). Ainda segundo Arendt, quando a produção das leis não é guiada pela lógica da ligação (lex), temos uma legislação que funciona como nomos, ou seja, leis restritivas, que 
separam e dividem os cidadãos. Ao contrário da lex, "que pressupõe uma cultura política democrática, fundamentada no diálogo cívico e no debate público", nomos "carrega o sentido de demarcação, fronteira, proibição, fixação de limites” (Barros, 2016, p.867). Em suma, a visão dos educadores se aproxima da visão republicana de lex.

Tabela 10 - Na sua opinião, ao fazer novas leis ou mudar as leis vigentes, o governo e o Congresso Nacional deveriam levar em conta:

\begin{tabular}{c|c|c}
\hline RESPOSTAS & Câmara & Senado \\
\hline A opinião de especialistas sobre o tema da lei & $5,3 \%$ & $3,1 \%$ \\
\hline A opinião dos partidos & $5,1 \%$ & $2,1 \%$ \\
\hline $\begin{array}{c}\text { A opinião de sindicatos, associações e entidades que representam } \\
\text { aqueles que serão diretamente afetados pelas leis }\end{array}$ & $4,2 \%$ & $2,3 \%$ \\
\hline A opinião da maioria da população & $16,1 \%$ & $13,2 \%$ \\
\hline Todas as alternativas & $69,3 \%$ & $79,3 \%$ \\
\hline Total & 100 & 100 \\
\hline
\end{tabular}

Fonte: Elaboração própria.

Quanto à obrigatoriedade do voto, a opinião predominante nos informantes das duas instituições é contra a medida adotada no Brasil, como mostra a Tabela 11. Segundo os respondentes:

- Não é democrático obrigar o cidadão a votar.

- Voto opcional é mais democrático.

- Não é a obrigatoriedade que qualifica a participação.

- Não devo ser obrigado a exercer um direito.

Por outro lado, os que são a favor da obrigatoriedade, explicam que

- Brasil ainda está jovem na democracia para instituir o voto facultativo.

- Entendo que o voto obrigatório é uma forma de obrigar o cidadão a se aproximar da política. Há uma certa função pedagógica nisso.

- Ainda não temos maturidade para exercer o voto facultativo no Brasil.

A obrigatoriedade do voto continua sendo uma questão relevante no debate sobre a democracia brasileira (Elkins, 2000, p.128). Sua instituição em 1932 teve como justificativa exatamente o fortalecimento do regime democrático, sob o argumento de que "o voto obrigatório aumenta a representação de várias características demográficas importantes" (Elkins, 2000, p.128), ampliando as possibilidades de uma representação política mais democrática.Assim, o voto compulsório pode "encorajar indivíduos marginalizados a propor ideias, definir políticos responsivos, e buscar fazer diferença na forma como o governo funciona" (Elkins, 2000, p.128). No caso específico da sociedade brasileira, "onde existem 
níveis extraordinariamente altos de desigualdade e onde a transição para a democracia não está completada, tal catalisador é altamente desejável” (Elkins, 2000, p.128, p.130).

Por outro lado, também há críticas a esse sistema, com várias justificações. A mais recorrente é a de que as democracias mais avançadas já aboliram o voto obrigatório. Mas também se questiona como um direito político pode ser tornado obrigatório. Soares (2004, p.109) argumenta que, se o livre direito de voto "significa a plena aplicação do direito ou liberdade de expressão", caracteriza-se, portanto, "mais como um direito subjetivo do cidadão do que um dever cívico". Logo, para ser pleno, “esse direito deve compreender tanto a possibilidade de se votar como a consciência determina, quanto a liberdade de abster-se de votar sem sofrer qualquer sanção do Estado" (Soares, 2004, p. 109). O mesmo autor aponta ainda os seguintes argumentos:

- O voto facultativo melhora a qualidade do pleito eleitoral pela participação de eleitores conscientes e motivados, em sua maioria;

- A participação eleitoral da maioria decorrente do voto obrigatório é um mito;

- É ilusão acreditar que o voto obrigatório possa gerar cidadãos politicamente evoluídos (SOARES, 2004, p.109).

Tabela 11 - Você concorda com o voto obrigatório?

\begin{tabular}{|c|c|c|}
\hline Respostas & Câmara & Senado \\
\hline Não & $89,90 \%$ & $77,40 \%$ \\
\hline Sim & $6,20 \%$ & $19,30 \%$ \\
\hline Em termos & $3,90 \%$ & $3,30 \%$ \\
\hline Total & $100,00 \%$ & 100,00 \\
\hline
\end{tabular}

Fonte: Elaboração própria.

Por se tratar de uma questão relevante no âmbito da educação para a democracia, indagamos se os informantes concordam com a proposta de "escola sem partido". 7 A Tabela 12 mostra uma rejeição expressiva à proposta. Os argumentos são os seguintes:

- É uma deturpação da ideia de educação pluralista e crítica.

-O movimento "escola sem partido"se traveste de defensor da "neutralidade" no ambiente escolar, para esconder o propósito de manipular a consciência

7 Trata-se do Projeto de Lei do Senado no 193/2016, de autoria do senador Magno Malta (PR-ES), que inclui entre as diretrizes e bases da educação o "Programa Escola sem Partido". Existem ainda vários outros projetos de lei sobre o mesmo tema tramitando na Câmara dos Deputados. Todos têm como objetivo evitar a "doutrinação ideológica" nas escolas, impedindo que professores se manifestem sobre questões político-partidárias na sala de aula. A proposta é inspirada na campanha homônima, liderada pelo advogado Miguel Nagib, desde 2004, que criou o movimento “Escola Sem Partido”. Trata-se de iniciativas distintas, embora o movimento tenha servido de fonte para os referidos projetos. 
dos jovens impedindo o desenvolvimento da consciência crítica dos mesmos.

- A educação é um ato político e nunca deixará de ser.

- Porque o projeto foi criação dos setores mais reacionários da sociedade. Nunca houve partido nas escolas. São artimanhas para controlar e perseguir os professores.

Os informantes que são favoráveis ao projeto, por sua vez, argumentam que:

- A escola não é lugar para se fazer política no sentido partidário.

- Ideologia política não deve interferir na educação.

- Democracia pressupõe liberdade de escolhas. Estudantes doutrinados têm sua liberdade de escolha usurpada.

- O problema é a esquerdização predominante nas disciplinas de ciências humanas.

É oportuno esclarecer que os defensores do projeto argumentam que o objetivo é "eliminar a discussão ideológica no ambiente escolar, restringir os conteúdos de ensino a partir de uma ideia de neutralidade do conhecimento" (Dutra; Moreno, 2016, sem paginação). Os críticos, por sua vez, justificam que

Trata-se de uma elaboração que contraria o princípio constitucional do pluralismo de ideias e de concepções pedagógicas, assim como o da liberdade de aprender, ensinar, pesquisar e divulgar o pensamento, a arte e o saber, considerando como válidos determinados conteúdos que servem à manutenção do status quo e como doutrinários aqueles que representam uma visão crítica (DUTRA; MORENO, 2016, sem paginação).

Como vimos, os educadores consultados são majoritariamente contrários ao projeto, embora haja informantes a favor. Certamente este constitui um tema relevante para debate nos programas de educação para a democracia, posto se tratar de uma questão que se tornou igualmente importante no debate público de modo geral.

Os críticos da proposta, conforme os trechos acima, ressaltam três argumentos básicos: (a) a necessidade de uma educação capaz de conduzir os estudantes ao raciocínio crítico, de forma pluralista; (b) a educação é inerentemente política, o que torna inviável a proposta; (c) o projeto "escola sem partido" constitui uma forma de controle político da educação, especialmente dos professores. Já os defensores da ideia consideram a proposta necessária porque, em sua visão, o ensino tornou-se "ideologizado" e partidarizado, com uma percepção de que os professores fazem doutrinação política em vez de debate crítico e pluralista. As duas perspectivas, na realidade, expressam a polarização existente no debate político brasileiro atual, manifesto no confronto entre as propostas da esquerda (especialmente o PT) e do centro-direita (principalmente o PSDB). 
Vários estudos analisam o projeto "escola sem partido" como sendo "um movimento conservador que busca mobilizar princípios religiosos, a defesa da família em moldes tradicionais e a oposição a partidos políticos de esquerda e de origem popular" (Macedo, 2017, p. 509). A proposta é considerada restritiva a uma educação em conformidade com os valores republicanos, além de uma "imposição de mordaça aos educadores" (Frigotto, 2016, p.11). Ao se referir ao conjunto de projetos que tramitam no Congresso Nacional sobre o tema, Ramos e Stampa (2016, p. 250) afirmam que

esses projetos buscam neutralizar o trabalho docente e direcionar o currículo, impedindo a circulação de conceitos marxistas, os debates sobre gênero e sexualidade nas escolas e submetendo os processos pedagógicos às convicções morais e religiosas dos pais. Tais imposições surgem num contexto de recrudescimento de forças conservadoras que, a princípio, pretendem "amordaçar" os professores, tornando-os meros reprodutores de discursos que conformem os alunos diante das desigualdades sociais, da intolerância religiosa e do preconceito de gênero, materializando um amplo retrocesso nas conquistas democráticas.

Para os autores,

ao tentar controlar o trabalho docente, o Programa Escola Sem Partido busca redefinir o currículo, invocando uma falsa neutralidade, que nega ao professor e ao aluno o direito de serem sujeitos na construção do conhecimento. No entanto, partimos do princípio de que a definição do que deve ou não ser ensinado nunca é um processo neutro, mas sempre representa ao mesmo tempo a trajetória e o resultado de correlações de força, ou seja, são projetos de formação humana antagônicos. Tanto o que será ensinado como o que será omitido fazem parte de um processo político e ideológico seletivo (RAMOS; STAMPA, 2016, p.250-251).

Convém ressaltar ainda que, conforme os dados apresentados, há um grupo de respondentes que expressa simpatia ao projeto “escola sem partido". São 16,80\% no Senado e 10,80\% na Câmara. Cabe ressaltar que são educadores que atuam em projetos institucionais de educação para a democracia.

Tabela 12 -Você é a favor do projeto "Escola sem partido"?

\begin{tabular}{|l|c|c|}
\hline RESPOSTAS & CÂMARA & SENADO \\
\hline Não & $83,00 \%$ & $75,80 \%$ \\
\hline Sim & $10,80 \%$ & $16,80 \%$ \\
\hline Em termos & $6,20 \%$ & $7,40 \%$ \\
\hline Total & 100,00 & 100,00 \\
\hline
\end{tabular}

Fonte: Elaboração própria. 


\section{Considerações finais}

O estudo teve como propósito analisar os valores políticos dos agentes pedagógicos que atuam nos programas de educação para a democracia nas duas casas do Congresso Nacional. Para tanto, foram incluídas várias perguntas no questionário, relacionadas direta ou indiretamente com valores políticos. Os dados revelam que os educadores consultados são críticos em relação ao atual estágio da democracia e ao combate à corrupção. Isso se explica certamente pela conjuntura crítica resultante das sucessivas crises políticas enfrentadas pelo Brasil no contexto recente.

Os dados revelam um perfil progressista em termos de adesão a valores políticos como igualdade, participação política, novos arranjos familiares, entre outros. Destaca-se ainda o predomínio de opiniões contrárias ao foro jurídico especial para parlamentares e favoráveis à afirmação de que os partidos políticos são necessários à democracia. Embora com a ressalva de que os partidos foram avaliados apenas sob a perspectiva do papel formal deles no sistema político. Por outro lado, convém ressaltar a existência de um grupo alinhado com as pautas conservadoras. Um exemplo são os 8,80\% dos educadores do Senado que acham que apenas a família formada por um homem e uma mulher merece a proteção do Estado. No caso do projeto "escola sem partido", há 16,80\% de respondentes do Senado que são favoráveis e 10,80\% da Câmara. Além disso, há 6,80\% dos respondentes que se declaram de direita; $6,60 \%$ de centro-direita, e 50,10\% de centro. Nesse último caso, há estudos que mostram que essa autodenominação expressa, na realidade, uma forma de "direita envergonhada" (Madeira; Tarouco, 2010).

Destoa do conjunto das respostas dos informantes a percepção sobre o voto do eleitor brasileiro, com mais de 60\% de respostas que afirma que o eleitor brasileiro não sabe votar. Trata-se de uma percepção crítica, mas que expressa preconceitos, no sentido de visões preconcebidas sobre o comportamento eleitoral da população, com tendências a culpar o eleitor pela situação política de crise, conforme argumentos expostos pelos próprios respondentes. Além do efeito de terceira pessoa, como já foi ressaltado anteriormente, tais percepções tendem a desconsiderar o contexto em que o voto é exercido, bem como a força do marketing político, as regras eleitorais, a influência dos fatores econômicos nas campanhas e os duelos simbólicos representados pela mídia nos debates políticos.

Em suma, o texto apresenta dados que são relevantes para a compreensão do modo de pensar de um segmento que atua diretamente nos projetos de educação para a democracia nas duas casas do Congresso Nacional. Uma contribuição do estudo, portanto, está no fato de identificar os educadores do Congresso Nacional como agentes de disseminação de valores políticos, além de registrar o uso de surveys com este público na literatura sobre educação para a democracia na atualidade. Como já foi destacado, os projetos institucionais de educação para a democracia mantidos por instituições legislativas são recentes no Brasil. Além disso, os estudos existentes até o momento privilegiam os efeitos de tais iniciativas, sem considerar a perspectiva dos educadores, como se fosse possível implantar programas educativos sem a atuação direta de educadores. Cabe ressaltar ainda 
que a base da educação para a democracia são os valores democráticos, cujos agentes de disseminação são os agentes pedagógicos.

\section{Referências}

ABEL. Escolas do legislativo. Disponível em: <http://www.portalabel.org.br/>. Acesso em: 4 jan. 2018.

ALLAN, Julie. Daring to think otherwise? Educational policymaking in the Scottish Parliament. Journal of Education Policy, v.18, n.3, p.289-301, 2003.

ALMOND, Gabriel A.;VERBA, Sidney. The civic culture. Princeton, Nova Jersey: Princeton University Press, 1989 [1963].

ALLPORT, Gordon W.;VERNON, Philip E.; LINDZEY, Gardner. Study of values. Oxford: Houghton Mifflin, 1972.

ALMEIDA RIBERTI, Felisbino; KERBAUY, Maria Teresa Miceli. Os valores políticos da democracia nas opiniões dos vereadores de São Bernardo do Campo, Santo André e São Caetano do Sul. Pensamento Plural, n. 10, p. 155-180, 2014.

ARENDT, Hannah. O que é política? Rio de Janeiro: Bertrand Brasil, 2004.

BALBACHEVSKY, Elizabeth; HOLZHACKER, Denilde. O novo consenso da sociedade brasileira: democracia e igualdade. Opinião Publica, Campinas, v.17, n.2, p.493-515, 2011.

BARROS, Antonio Teixeira. Educação e legislação. Educação E Sociedade, v. 37, n. 136, p. 861-872, 2016.

BARROS, Antonio Teixeira de; MARTINS, Lúcio Meireles. Impactos do Parlamento Jovem brasileiro na imagem pública do Poder Legislativo na visão dos egressos. Revista do Serviço Público, v. 68, n.1 p.157-190, 2017a.

.Juventude e engajamento político despartidarizado. Latitudes. (Aguardando publicação). 2017b.

Juventude e política na experiência de dez anos do Parlamento Jovem Brasileiro Sociologias. (Aguardando publicação). 2017c.

BENEVIDES, Maria Victoria de Mesquita. Educação para a democracia. Lua Nova, n.38, p.223-237, dez. 1996.

BORBA, Julian. Participação política: uma revisão dos modelos de classificação. Sociedade e Estado, v.27, n.2, p.263288, 2012.

BRAGA, Sergio Soares; MITOZO, Isabele Batista; TADRA, Julia. As funções desempenhadas pelos websites parlamentares brasileiros e o papel dos programas educativos. Educação E Sociedade, v.37, n.136, p.793-819, 2016.

CARVALHO, Alexandre Ventura Caçador. O Parlamento Jovem e a experiência das Escolas do Legislativo mineiro e da Câmara dos Deputados. 2009. Trabalho de Conclusão de Curso (Especialização) - Centro de Formação da Câmara dos Deputados, Brasília, 2009.

CARVALHO, Vânia Nunes de. Legislativo educativo: o caso do Programa "Missão Pedagógica no Parlamento" da Câmara dos Deputados. 2014. 125f. Dissertação (Mestrado em Ciência Política) - Centro de Formação da Câmara dos Deputados, Brasília, 2014.

CASALECCHI, Gabriel Ávila. Socialização política e mudanças de atitudes: a experiência do Parlamento jovem Mineiro 2008. 2011. 219f. Tese (Doutorado) - Programa de Pós-Graduação em Ciência Política da Universidade Federal de Minas Gerais, Belo Horizonte, 2011.

COPPEDGE, Michael; GERRING, John; LINDBERG, Staffan, I. Variedades de democracia (V-Dem): un enfoque histórico multidimensional y desagregado. Revista Española de Ciencia Política, n.30, p.97-109, 2012.

COSSON, Rildo. Dois modelos de parlamento jovem. Estudos Legislativos, v.3, p.34-45, 2009.

Escolas do legislativo: escolas de democracia. Brasília: Edições Câmara, 2008. 
Letramento político: por uma pedagogia da democracia. Cadernos Adenauer, Rio de Janeiro, v.11, n.3, p.25-36, 2010.

Letramento político: trilhas abertas em um campo minado. E-legis, Brasília, n.7, p.49-58, 2011.

Letramento político no legislativo: a experiência do Programa Estágio Visita. 2015. Tese (Doutorado em Educação) - Faculdade de Educação, Universidade Federal de Minas Gerais, Minas Gerais, 2015.

CRICK, Bernard. Qualifications and curriculum authority. In: Education for citizenship and the teaching of democracy in schools: final report of the Advisory Group on Citizenship. London: QCA, 1998. Disponível em: <http://dera. ioe.ac.uk/4385/1/crickreport1998.pdf>. Acesso em: 23 nov. 2016.

Education for citizenship: the citizenship order. Parliamentary Affairs, v.3, n.55, p.488-504, 2002.

2007.

Citizenship: the political and the democratic. British Journal of Educational Studies, v.55, n.3, p. 235-248,

DAVISON, W. Phillips. The third-person effect in communication. Public opinion quarterly, v.47, n. 1, 1-15, 1983.

DUTRA, Cláudia; MORENO, Camila. Escola sem partido. Carta Capital, 8 ago. 2016. Disponível em:

$<$ https://www.cartacapital.com.br/educacao/escola-sem-partido-estrategia-golpista-para-calar-a-educacao>. Acesso em: 28 maio 2017.

ELKINS, Zachary. Quem iria votar? Conhecendo as consequências do voto obrigatório no Brasil. Opinião Pública, v.6, n.1, p.109-136, 2000.

FINKEL, Steven E. Can democracy be taught? Journal of Democracy, v.4, n.4, p. 137-15, 2003.

FINKEL, Steven, E.; SMITH, Amy Erica. Civic education, political discussion, and the social transmission of democratic knowledge and values in a new democracy: Kenya 2002. American Journal of Political Science, v.55, n.2, p.417-435, 2011.

FRIGOTTO, Gaudêncio. "Escola sem partido": imposição da mordaça aos educadores. e-Mosaicos, v. 5, n. 9, p. 11-13, 2016.

FUKS, Mario; CASALECCHI, Gabriel. Trust and political information: attitudinal change among participants in the Youth Parliament in Brazil. Brazilian Political Science Review, São Paulo, v.6, n.1, p.70-88, 2012. 449, 2014.

Explicando os efeitos de programas de socialização política. Opinião Pública, Campinas, v.20, n.3, p.425-

GONÇALVES, Guilherme Quaresma; CASALECCHI, Gabriel Ávila. O impacto do Parlamento Jovem sobre a confiança dos jovens mineiros. Cadernos da Escola do Legislativo, Belo Horizonte, v.15, n.24, p.71-106, 2013.

HENRIQUE, Ana Lúcia. O que pensa quem "bate à porta” de uma Casa que só "apanha”? Percepções e orientações dos visitantes sobre o Congresso Nacional. Opinião Pública, v.19, n.2, p.346-379, Nov. 2013.

Quem disse que mulher não gosta de política? Uma análise da representação feminina no Parlamento Jovem Brasileiro. Cadernos da Escola do Legislativo, Belo Horizonte, v.18, n.29, P. 55-86, jan./jun. 2016.

JOHNSON, Allan G.Valores. In:JOHNSON, Allan G. Dicionário de sociologia. Rio de Janeiro: Zahar, 1997. p.247248.

LAVALLE, Adrian G.,VERA, Ernesto Isunza. A trama da crítica democrática: da participação à representação e à accountability. Lua Nova, v.84, p.353-64, 2011.

LESTON-BANDEIRA, Cristina. Parliamentary functions portrayed on European parliaments' websites. Revista de Sociologia e Politica, v. 17, n. 34, p. 13-27, 2009.

Studying the relationship between Parliament and citizens. The Journal of Legislative Studies, v. 18, n. 3-4, p. 265-274, 2012.

LLOYD, John. Tom Johnston's Parliament on education: the birth of the Sixth Advisory Council on Education in Scotland, 1942-43. Scottish Educational Review, v.16, n.2, p.104-16, 1984. 
LIMA, Maria Regina Soares; CHEIBUB, Zairo Borges. Instituições e valores: as dimensões da democracia na visão da elite brasileira. Revista Brasileira de Ciências Sociais, v. 11, p. 83-110, 1996.

MACEDO, Elizabeth. As demandas conservadoras do movimento Escola Sem Partido e a Base Nacional Curricular Comum. Educação \& Sociedade, v. 38, n.139, p. 507-524, 2017.

MADEIRA, Rafael M.;TAROUCO, Gabriela. A “direita envergonhada” no Brasil: como partidos reinterpretam seus vínculos com o regime militar. In: CONGRESSO LATINO-AMERICANO DE CIÊNCIA POLÍTICA, 5. Anais... Buenos Aires, 2010.

MANFREDA, Katija, Losar;VEHOVAR,Vasja. Internet survey. In: LEEUW, Edith Desirée; HOX, J.J.; DILLMAN, Don A. (Ed.). International handbook of survey methodology. London: Taylor \& Francis, 2008. p.264-283.

MANRÍQUEZ, Mario Sandoval. Sociología de los valores y juventud. Última década, v. 15, n.27, p.95-118, 2007. MANUEL, Linda. Família e democracia. Humanística e Teologia, Lisboa, n.16, p.95-108, 1995.

MARQUES JÚNIOR, Alaôr Messias. Educação legislativa: as escolas do legislativo e a função educativa do Parlamento. E-Legis, Brasília, n.3, p.73-86, 2009.

MARTINS, Lúcio Meireles. Impactos do Parlamento Jovem Brasileiro no comportamento político dos egressos (2006 a 2014). 2017. 87 f. Dissertação (Mestrado em Ciência Política) - Centro de Formação da Câmara dos Deputados, Brasília, 2017.

MESSIAS JÚNIOR, Alaor M. Educação legislativa: as escolas do legislativo e a função educativa do Parlamento. E-Legis, Brasília, v.3, n. 3, p. 73- 86,jul./dez. 2009.

MOISÉS, José A. Cultura política, instituições e democracia: lições da experiência brasileira. Revista Brasileira de Ciências Sociais, v. 23, n. 66, p.11-43, 2008.

ODDONE, Sílvia Castanheiro. O Programa Senado Jovem Brasileiro. 2015. 64 f. Trabalho de Conclusão de Curso (Especialização) - Instituto Legislativo Brasileiro, Senado Federal, Brasília, 2015.

OLIVEIRA, Maria Alice et al. Competências a desenvolver na educação para a democracia. E-Legis, Brasília, n.20, p.102-118, 2016.

OPPO, A. Socialização política. In: BOBBIO, N.; MATTEUCCI, N.; PASQUINO, G. (Orgs.) Dicionário de política. Brasília: Editora da UnB, 2000. p. 1202-1206.

PARRY, Richard. The Scottish Parliament and social policy. Scottish Affairs, v.20, n.1, p.34-46, 1997.

PATERSON, Lindsay. Education, local government and the Scottish Parliament. Scottish Educational Review, v. 30 , p. 52-60, 1998.

PERISSINOTTO, Renato M.; BRAUNERT, Mariana B. A direita, a esquerda e a democracia: os valores políticos dos parlamentares paranaenses (1995-2002). Opinião Pública, v. 12, n. 1, p. 114-135, 2006.

RAMOS, A. Social values dynamics and socio-economic development. Portuguese Journal of Social Science, v.5, n.1, 35-64, 2006.

RAMOS, Marise Nogueira. A pedagogia das competências: autonomia ou adaptação?. Campinas: Cortez, 2000.

RAMOS, Moacyr Salles; STAMPA, Inez. Subversão e resistência docente: notas sobre a ditadura militar e o movimento Escola sem Partido. Revista Espaço do Currículo, v. 9, n. 2, p.249-270, 2016.

RIBEIRO, Guilherme Wagner. Informação, aprendizagem e inovação nas Câmaras Municipais de Minas Gerais. 2010. 231 f. Tese (Doutorado em Ciências Sociais) - Pontifícia Universidade Católica de Minas Gerais, Minas Gerais, 2010 .

ROCHA, Hérycka Sereno Neves. Educação para a democracia: desafios e perspectivas a partir da análise do perfil dos participantes dos programas Estágio-Visita de Curta Duração e Parlamento Jovem Brasileiro da Câmara dos Deputados. 2016. Dissertação (Mestrado Profissional em Poder Legislativo) - Centro de Formação da Câmara dos Deputados, Brasília, 2016. 
SCHWARTZ, S. H.; BILSKY, W. (1990). Toward a theory of the universal content and structure of values: extensions and cross-cultural replications. Journal of Personality and Social Psychology, v. 58. n. 5, p. 878-891.

SETTON, Maria da Graça Jacintho. A particularidade do processo de socialização contemporâneo. Tempo Social, v. 17, n.2, p.336, 2005.

SOARES, Paulo Henrique. Vantagens e desvantagens do voto obrigatório e do voto facultativo. Revista de Informação Legislativa, v.41 n.161, p.107-116, 2004.

SCHEEFFER, Fernando. Esquerda e direita: velhos e novos temas. In: ENCONTRO ANUAL DA ANPOCS, 38. Anais.. Caxambu, 2014.

TAROUCO, Gabriela da Silva; MADEIRA, Rafael Machado. Esquerda e direita no sistema partidário brasileiro: análise de conteúdo de documentos programáticos. Revista Debates, v.7, n.2, p.93-114, 2013.

TOMIZAKI, Kimi; CARVALHO-SILVA, Hamilton Harley de; SILVA, Maria Gilvania Valdivino. Socialização política e politização entre famílias do Movimento dos Trabalhadores Sem Teto. Educação \& Sociedade, v. 37, n. 137, p. $935-954,2016$.

VIANA, Nildo. Os valores na sociedade moderna. Brasília:Thesaurus Editora, 2007. 


\title{
Political values of pedagogical agents of education projects for democracy of the Brazilian National Congress
}

\begin{abstract}
:
This article analyzes the perception and the discourse of the pedagogical agents that act in the programs of education for the democracy of the National Congress. The study was conducted through websurvey, with questions open and closed in May 2017. The main conclusions show that educators are critical of the current stage of democracy and the fight against corruption. There is high adherence to political values such as equality of rights, political tolerance, respect for cultural and sexual difference and diversity, new family configurations, political and social participation, among others. The study presents data that are relevant to understanding the way of thinking of a segment that acts directly in the projects of education for democracy in the two houses of the National Congress, considering that the studies have privileged the effects of such initiatives, without considering the perspective of educators.
\end{abstract}

Keywords: Education for democracy, Political values, Brazilian National Congress, Brazilian Chamber of Deputies, Brazilian Senate.

\section{Valores políticos de los agentes pedagógicos de los proyectos de educación para la democracia del Congreso Nacional brasileño}

\section{Resumen:}

El artículo analiza la percepción y el discurso de los agentes pedagógicos que actúan en los programas de educación para la democracia del Congreso Nacional. El estudio fue realizado por medio de websurvey, con preguntas abiertas y cerradas en el mes de mayo de 2017. Las principales conclusiones demuestran que los educadores son críticos en relación al actual estadio de la democracia y al combate a la corrupción. Hay elevada adhesión a valores políticos como igualdad de derechos, tolerancia política, respeto a la diferencia ya la diversidad cultural y sexual, nuevas configuraciones familiares, participación política y social, entre otros. El estudio presenta datos que son relevantes para la comprensión del modo de pensar de un segmento que actúa directamente en los proyectos de educación para la democracia en las dos casas del Congreso Nacional, considerando que los estudios han privilegiado los efectos de tales iniciativas, sin considerar la perspectiva De los educadores.

Palabras-clave: Educación para la democracia,Valores políticos, Congreso Nacional brasileño Camara de los Diputados brasileña, Senado brasileño. 